\title{
APPLICATION OF GIS-PLANNING DECISION SUPPORT SYSTEM IN PREDICTING DEVELOPMENT IMPACT ASSESSMENT
}

\author{
M. Asmawi ${ }^{\mathrm{a}}$, M. F. Abdullah ${ }^{\mathrm{a}}$, A. Abdullah ${ }^{\mathrm{a}}$, M. N. A. Shahbuddin ${ }^{\mathrm{b}}$ \\ ${ }^{a}$ KAED, International Islamic University Malaysia, Kuala Lumpur, Malaysia - (zainora, mfaris, dralias)@iium.edu.my \\ b IIUM Entrepreneurship and Consultancies Sdn. Bhd., International Islamic University Malaysia, Kuala Lumpur, \\ Malaysia - azraeishahbudin@gmail.com
}

\section{Commission IV/8}

KEY WORDS: Development impacts assessment, Modelling, Projection, Environment, Social, Economy

\begin{abstract}
:
Impact of development is a major issue of global environment change. The modelling and projecting of development are essential to the assessment of consequent environmental impacts. Thus, this research was conducted to develop a customised modelling system that integrates the strength of GIS in supporting planning decision making process via prediction of development impact assessment for various projects. It is in this respect that a prototype of GIS-based modelling that enables to anticipate developmentenvironmental impacts at an early stage of project planning has been established. It encompasses some selected key components of environment, economy and social, building up the system called e-Development Impact Assessment (e-DIA). The design principle was to extend the functionality of a GIS system in facilitating planning decision support making process. An integrated subsystem of e-DIA allows the analysis of environmental, social and economic dimensions to generate the results of impacts of proposed development in the form of spatial and textual data. In terms of environmental impact assessment, e-DIA acts as a screening/scoping utility which may indicate the potential impacts of a set of pre-determined environmental impacts. For social and economic impact assessments, the e-DIA computes the outcome of future demand for social facilities, future employment opportunity and parking requirement.
\end{abstract}

\section{INTRODUCTION}

\subsection{General overview}

The last decade of research on global environmental change has identified a series of core concerns on quality of life, particularly the issue of development impacts. Considerable attention has been given to the potential impacts of development growth. In town planning field, the term 'wicked problems' refers to a complex phenomenon emerged as development evolves in which it affects the positive and negative implications of development. However, the existence of several external factors such as the geographical distribution of impacts, the time in which they will take place, as well as future scenarios are still surrounded by much uncertainty and probability (Schneider et al., 2001; Wilbanks et al., 2007). The environmental impact has become a great concern. As such, many scientists develop advanced techniques and technology to find the answer and solution for the arising problems in relation to the environment. In this regards, the evolution of computer science and technology has facilitated significantly the process of decision making in many fields. Among others is the exploration of the usage and ability of Geographic Information Systems (GIS). It is acknowledged that GIS has the ability to perform complicated and difficult analysis tasks, making them are promptly raising growing interest among environmental experts around the globe.

Recently, much effort had been devoted by computer science researchers to enhance the usability of GIS, so as to allow domain experts to learn the use of those systems and fully exploit their functionality in many fields, including geography, environment, oceanography and many others (Nedović-Budić, 2000; Vlado, 1993). Town planning is no exception though the acceptance level of planners was rather low in the early stage of the introduction of GIS in planning profession (Abdullah, Abdullah \& Zahari, 2010; Geertman, 2002; Nedović-Budić, 2000 \& Gocmen, 2009). The contemporary age of planning indicates that after two decades since the introduction of GIS into the planning field, GIS has become an important tool (Drummond \& French, 2008; Gocmen, 2009). Thus, this research studied the development of GIS-based system in the complex system of the nature of environmental settings, reflecting the potential results into a designed reality with the assistance from computer aided tool. The aim of the paper is to address the application of GIS as a Planning Decision Support System (PDSS) in the field of environment in which a dedicated system called e-Development Impact Assessment (e-DIA) was developed as a prototype for further improvement and future needs.

\subsection{The needs of impact assessment}

In general, development growth has been viewed as positive effort and desirable for communities at large because it often leads to value-added actions such as, additional jobs, increased income for residents, and the enhancement of public facilities. However, it may also be accompanied by costs such as traffic congestion, reduction in air and water quality, and loss of open space. In addition, development decisions made by the authorities are too often made without a sufficient understanding of the consequences of those decisions on overall 
community well-being. Therefore, cautiously planned development is crucial for ensuring that growth is consistent with the long-range goals of the overall planning, particularly when it relates with the environmental considerations. This demonstrates the importance of applying advanced modelling and projecting techniques in assessing the consequent environmental impacts. Thus, this research was conducted to develop a customised modelling system that integrates the strength of GIS in supporting PDSS via prediction of DIA for various projects. It is in this respect that a prototype of GISbased modelling that enables to anticipate developmentenvironmental impacts at an early stage of project planning has been established. It encompasses some selected key components of environment, economy and social, building up the system called e-DIA. The working definition for e-DIA is "a computer system that helps early-prediction of the environmental, social and economic impacts of development, in spatial and textual data, operated by using a structural computer model. The results will include a checklist of the possible environmental and socio-economic impacts that may require further considerations by the authorities in granting approval to applications for development". It is important to emphasis here that the present version of e-DIA was only designed and developed strictly as an early-stage planning information system to assist planning authorities in assessing limited number of potential impacts of a proposed development. It is designed to assist planners of planning authorities in understanding, ahead of time, what types of impacts a particular development may have on a community. It is anticipated that community at large would enjoy the benefits gained from the establishment of eDIA, covering many aspects: addressing the range of potential impacts associated with a proposed development; offering early identification of potential impacts of proposed development; improving decision making process; increasing working efficiency; identifying resource needs and constraints; promoting fairness and consistency in the planning process.; allowing work process integration; and promoting user friendly impact assessment system.

\section{SYSTEM ARCHITECTURE}

\subsection{Institutional network}

Development impact assessment (DIA) involves a process to comprehensively evaluate the consequences of development on a community. The assessment process should be an integral part of the overall planning and development process as it provides extensive documentation of the anticipated economic, fiscal, environmental, social and transportation-related impacts of a particular development on a community. In the context of town planning field, Laurini (1978 \& 2001) mentioned that a city or town consists of a general system and its interconnected subsystems (Figure 1). This could also be referred to as wickedproblems that denote a set of defining characteristics (refer to Horn and Weber, 2007). This complicated scenario justifies the needs for the e-DIA system, in order to facilitate planners at the authorities in making planning decisions.

In this regards, the DIA process makes use of existing information available, where possible to determine potential impacts of a proposed development. The e-DIA system provides a framework to integrate these data, models, spatial and statistical analyses and experiences in other locales to predict potential development impacts.

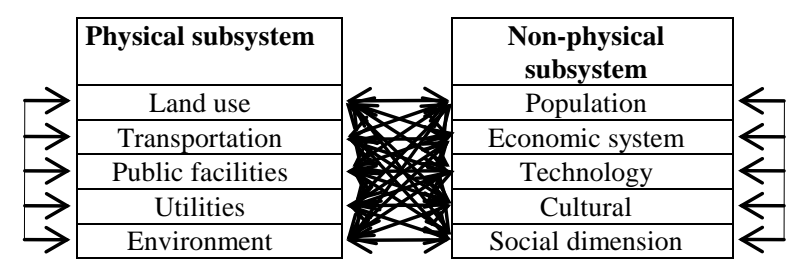

Figure 1: Wicked problems and its associated subsystems in a town

\subsection{Technological network}

The architectural for information system for e-DIA is a clientserver design. In principle, the domain of client-server relates with the export of some treatments and some data to different locations, linking to a data and application server (Laurini, 2001). The framework in Figure 2 provides an overview of the key contingent variables that influence impact assessment and outlines how users commence the decision-making process by assessing the level of criteria. The use of 'what if' scenarios can help to explore consequences of physical effects and impact assessment (Klosterman \& Pettit, 2005; Svedin \& Aniansson, 1987; Swart, Raskin \& Robinson, 2004). Expert knowledge gathered in a 'what-if' scenario analysis can help charting possible complex linkages between criteria in which planning database is derived by compiling data from multiple sources. In this case, the structure of database management system follows the model of hierarchical spanning tree (Laurini \& Thompson, 1999), involving a set of criteria and its sub-criteria.

\subsection{Setting the scene}

The e-DIA is a GIS-based decision support system that is developed to analyse potential impacts that may arise from a proposed development. It is specifically developed for the use of the TCP officers, especially in dealing with planning applications. Figure 2 depicts the overview of the e-DIA system architecture.

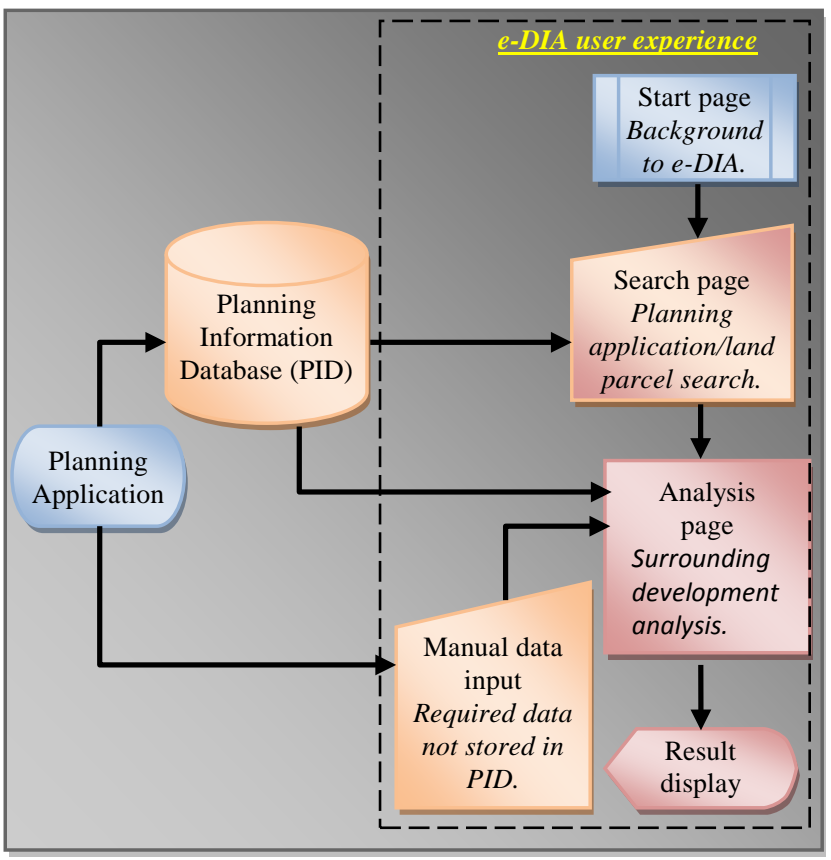

Figure 2: Overview of the e-DIA system 
The user experience of the e-DIA can be categorised into four sections, which are the start page, the search page, the analysis page and the result display page. Upon executing e-DIA application, user will be presented with a start page displaying brief introduction to e-DIA.

Following the introduction/start page, user will be presented with a search page from which user can begin to search for planning application or land parcel (Figure 3). The search page will load a map and its associated legend by default. Both of these are located on the left side of the page. The search tool is located on the right side of the page. The search tool provided allows user to search planning application or land parcel using different parameters such as by district, mukim, kampong or lot number. User can also refine the search by using a combination of the parameters. E-DIA will then search the planning authorities' Planning Information Database (PID) and will filter the information from the database according to the search parameters.

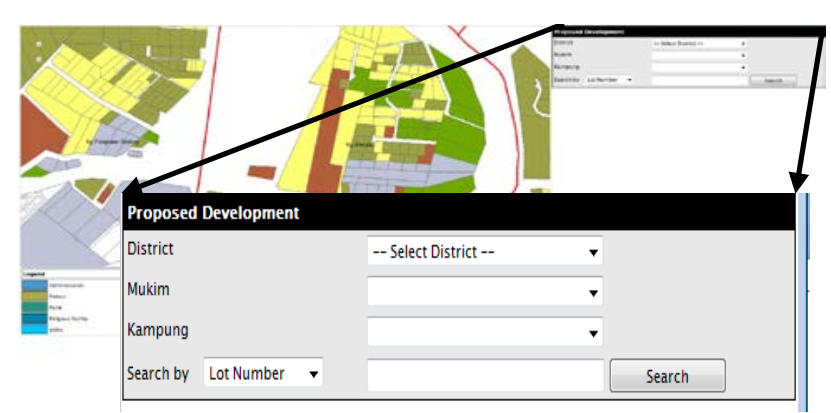

Figure 3: e-DIA search tool

A list planning applications which closely match the search parameters will then be displayed (Figure 4). From this list, user can select the planning application that he/she would like to analyse.

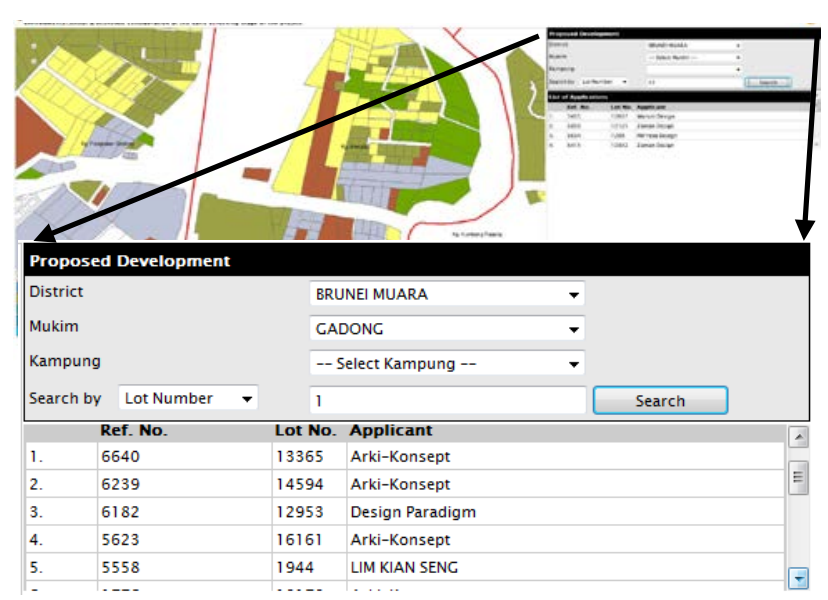

Figure 4: e-DIA search result

Selecting a planning application from the list of matching results will automatically bring user to the e-DIA analysis page. On this page, detail information about the selected application such as name of applicants, date of application, category of proposed development and lot number will be displayed (Figure 5). These detail information help user to determine whether he/she has selected the correct planning application.

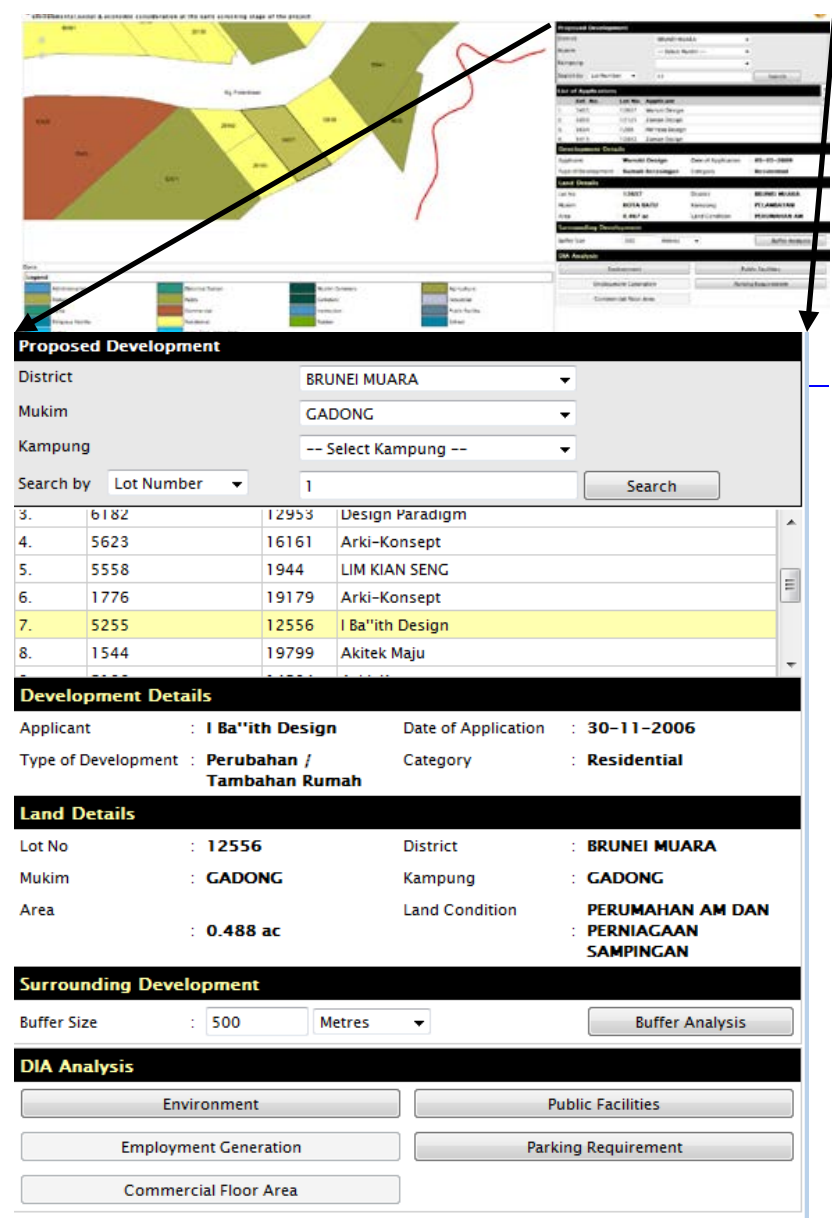

Figure 5: e-DIA analysis page showing detail information of selected planning application and analysis tools

Besides the detailed information of selected planning application, user can also find analysis tools on the e-DIA analysis page. e-DIA provides two types of analysis; surrounding development analysis and development impact analysis. The surrounding development analysis is effectively a buffer analysis to identify the types of development within a certain radius from the proposed development site. User will have to key in the buffer size and click the buffer analysis button. e-DIA will then list out all the land parcels located within that radius and their associated type of development.

\section{ANALYSIS OF THE E-DIA SYSTEM}

Meanwhile, the DIA analysis, as it name suggests, analyses the potential impacts of the development proposed by the planning application. The types of impacts to be analysed have been predetermined. These include environmental impact analysis, social impact analysis and economic impact analysis. A total of five analysis tool buttons are provided for user to perform impact analysis. Table 1 explains the function of each of the buttons. User can perform the analysis by clicking on the analysis tool buttons (Figure 6). For the purpose of this paper, the authors address the environmental impact analysis as the case study in which its model represents the common principles, analytical process and structure for the other types of impact in the e-DIA system. 


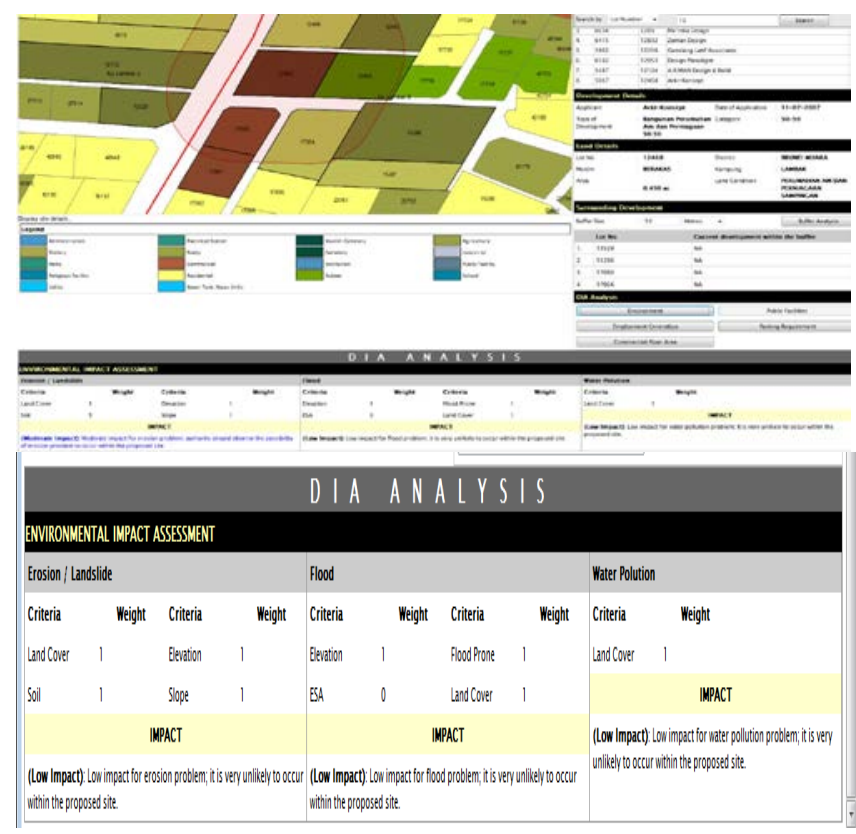

Figure 6: The e-DIA result display page showing the results of environment analysis

\begin{tabular}{|lll|}
\hline \multicolumn{1}{|c|}{$\begin{array}{c}\text { Analysis tool } \\
\text { button }\end{array}$} & \multicolumn{1}{c|}{$\begin{array}{c}\text { Type of } \\
\text { impact }\end{array}$} & \multicolumn{1}{c|}{ Description } \\
\hline Environment & $\begin{array}{l}\text { Environmental } \\
\text { impact }\end{array}$ & $\begin{array}{l}\text { Assess the potential impacts } \\
\text { of flooding, landslide and } \\
\text { water quality. }\end{array}$ \\
\hline Public Facilities & Social impact & $\begin{array}{l}\text { Assess the demand for public } \\
\text { facilities and the number of } \\
\text { facilities required. }\end{array}$ \\
\hline $\begin{array}{l}\text { Employment } \\
\text { Generation }\end{array}$ & $\begin{array}{l}\text { Economic } \\
\text { impact }\end{array}$ & $\begin{array}{l}\text { Estimate the number of } \\
\text { potential job to be created. }\end{array}$ \\
\hline $\begin{array}{l}\text { Parking } \\
\text { Requirement }\end{array}$ & $\begin{array}{l}\text { Economic } \\
\text { impact }\end{array}$ & $\begin{array}{l}\text { Calculate the number of } \\
\text { vehicle parking required. }\end{array}$ \\
\hline $\begin{array}{l}\text { Commercial } \\
\text { Floor Area }\end{array}$ & $\begin{array}{l}\text { Economic } \\
\text { impact }\end{array}$ & $\begin{array}{l}\text { Calculate the cumulative total } \\
\text { of commercial floor area in } \\
\text { the district. }\end{array}$ \\
\hline
\end{tabular}

Table 1: Description of the e-DIA development impact analysis tool buttons.

With the exception of parking requirement analysis, all the analyses built into the e-DIA were designed to utilise data that are extracted solely from the PID. For parking analyses, there are instances where user has to manually input certain information pertaining to the planning application that is not stored in the PID, such as the location of proposed development site (i.e. within municipal area or outside municipal area) and the category of proposed development (i.e. setback required or setback not required). Since these information are not stored in the PID, user will have to source them directly from the planning application documentations.

Despite the standard display of five analysis tool buttons, not all of the analysis is applicable to all types of proposed development. In fact, the types of analysis that can be performed are dependent on the types of development proposed by the planning application. For instance, analysis on environmental impacts can be performed on all types of proposed development, but analysis on employment generation can only be performed on commerce and industry development and not on housing development. Table 2 presents a matrix between types of proposed development and the applicable analyses.

\begin{tabular}{|c|c|c|c|c|c|}
\hline \multirow{2}{*}{ 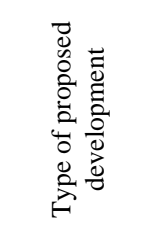 } & \multicolumn{5}{|c|}{ Type of analysis } \\
\hline & 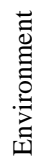 & :气 & 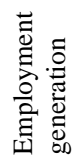 & 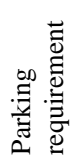 & 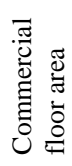 \\
\hline Residential & $\checkmark$ & $\checkmark$ & $x$ & $\checkmark$ & $x$ \\
\hline Commercial & $\checkmark$ & $x$ & $\checkmark$ & $\checkmark$ & $\checkmark$ \\
\hline Industry & $\checkmark$ & $x$ & $\checkmark$ & $\checkmark$ & $x$ \\
\hline
\end{tabular}

Table 2: Types of proposed development and applicable development impact analyses

Finally, following the analysis page, user will be presented with the result display page. On this page, the results of the analysis performed earlier by the user will be presented at the bottom portion of the page (Figure 6). User can capture the screen and print the result display page for record/filing purposes.

\section{ENVIRONMENTAL IMPACT ANALYSIS}

Environmental impact analysis has been developed with the intention to provide early prediction of possible impacts resulting from proposed development within an area. This analysis should not be regarded as a substitute for a formal detailed environmental impact assessment (EIA) report. Nevertheless, results derived from the e-DIA's environmental impact analysis are sufficiently acceptable to be used as basis for making decision at the planning authority's level. Additionally, should a more detailed EIA study is deemed necessary to be subsequently conducted, the results from the eDIA system can be used to determine the focus or scope of the study.

Based on the availability of data, the e-DIA environmental impact analysis is divided into three sub-analyses, which are: erosion/landslide analysis; flood analysis; and water pollution analysis. Ideally, the sub-analyses should include more than the three, covering bigger spectrum of environmental pollutions such as noise pollution and air pollution. Unfortunately, due to unavailability of relevant data, impact analysis of such pollution is not included in the present version of the e-DIA. However, in the future, should the data become available, it is advisable that the e-DIA be extended to make its environmental impacts analysis more comprehensive, for instance, by including analyses for air pollution and noise pollution.

In assessing potential environmental impacts, the e-DIA system emphasises on the analysis of the interaction between three mutually related factors namely, location, development action and environmental setting. Location refers to the proposed development site and its surrounding, development action refers to type of proposed development and environmental setting refers to a set of parameters that describe the proposed site in terms of its environmental assets and constraints. The parameters used are similar to those used in the analysis under the What If? subsystem. Weightage are then applied to the parameters to derive predicted impacts in all the sub-analyses. Table 3 lists the parameters and their associated weightage, 
while appendix 1 shows the flow process of the e-DIA reasoning (evaluation) process for the proposed e-DIA system, as shown in appendix 1 , all the selected parameters are stored in a union database (in PID) to generate analysis of environmental impacts. For instance, the analysis of erosion/landslide depends on parameters of land cover, soil, elevation and slope. The combination of these parameters is then divided into three levels of impacts, i.e. low impact, moderate impact and high impact. This process involves the application of procedural (inference) rules which determines the level of impacts.

\begin{tabular}{|c|c|c|}
\hline Parameters & Conditions of Site & Weightage \\
\hline \multirow{3}{*}{ Elevation } & $<100 \mathrm{~m}$ & 1 \\
\hline & $100-300 m$ & 2 \\
\hline & $>300 \mathrm{~m}$ & 3 \\
\hline \multirow{2}{*}{ Land cover } & Built-up area & 1 \\
\hline & Agriculture area & 2 \\
\hline \multirow{2}{*}{$\begin{array}{l}\text { Environmental } \\
\text { Sensitive Area }\end{array}$} & Non-ESA & 1 \\
\hline & ESA & 2 \\
\hline \multirow{4}{*}{ Slope } & $<12^{\circ}$ & 1 \\
\hline & $12-25^{\circ}$ & 2 \\
\hline & $25-30^{\circ}$ & 3 \\
\hline & $>30^{\circ}$ & 4 \\
\hline \multirow{5}{*}{ Soil } & Alluvium & 1 \\
\hline & Clay & 2 \\
\hline & Sand & 3 \\
\hline & Hill rock & 4 \\
\hline & Swamp & 5 \\
\hline \multirow{2}{*}{ Hydrology } & No water body within site & 1 \\
\hline & Water body within site & 2 \\
\hline \multirow{4}{*}{$\begin{array}{l}\text { Flood-prone } \\
\text { area }\end{array}$} & Outside flood-prone area & 1 \\
\hline & Within flood-prone area & 2 \\
\hline & $5-15$ ac & 2 \\
\hline & $>15$ ac & 3 \\
\hline
\end{tabular}

N.B.: If 0 appears in the analysis, it indicates that the data for specific parameter is unavailable

Table 3: Weighted parameters for the e-DIA environmental impact analysis

\section{CONCLUSION}

This paper presents e-DIA, a system developed for a specific purpose, i.e. to predict the potential impacts of the proposed development. The system applied the extended function of GIS in facilitating planners at the planning authorities in the process of making decision for the development application. The major theoretical contribution of this current paper is the development of a framework that extends research on the application of GISPDSS in predicting possible impacts due to the proposed development taking into account its geographical and environmental settings. Further to the theoretical contribution, this research has practical implications for decision-makers and planners in developing suitable mechanism in monitoring the planning application. Even though the number of impacts assessed by current system of e-DIA is limited, these are crucial impacts that can reasonably give the planning authorities early indication on the sustainability and feasibility of the proposed development.

During the process of developing the e-DIA system, it was also discovered that many more analyses could have been built into the sub-system provided that relevant data is available. For instance, inclusion of analyses on air and noise pollution would environmental impact analysis. For the construction of a typical have made the e-DIA much more comprehensive in terms of its assessment of impacts. This demonstrates that a good system of data capturing and storing is essential so as to allow for these analyses to be included into the e-DIA system in the future.

\section{References}

\section{References from Journals:}

Drummond, W.J. and French, S.P., 2008. The Future of GIS in Planning: Converging Technologies and Diverging Interests. Journal of the American Planning Association, 74 (2), pp. 161174.

Geertman, S., 2002. Participatory Planning and GIS: a PSS to Bridge the Gap. Environment and Planning. B, Planning \& Design, 29, pp. 21-35.

Klosterman, R. E. and Pettit, C.J., 2005. An Update on Planning Support Systems. Environment and Planning B: Planning and Design, 32 (4), pp. 477-484.

Nedović-Budić, Z., 2000. Geographic Information Science Implications for Urban and Regional Planning. URISA Journal. Vol. 12 (2), pp. 81-92.

Swart, R.J., Raskin, P. and Robinson, J., 2004. The problem of the future: sustainability science and scenario analysis. Global Environmental Change, 14, pp. 137-146.

\section{References from Books:}

Abdullah, M.F., Abdullah, A. and Zahari, R.K., 2010. GIS Implementation in Malaysian Statutory Development Plan System, in Handbook of Research on E-Planning: ICTs for Urban Development and Monitoring, pp. 435-454. Ed C.N. Silva. New York: Information Science Reference.

Klosterman, R. E., 2001. The What if? Planning Support System", in Planning Support Systems: Integrating Geographic Information Systems, Models and Visualization Tools, Eds R. K. Brail \& R. E. Klosterman (ESRI Press, Redlands, CA) pp. 263284.

Laurini, R., 1978. A Control Model for Urban Systems: an Explorative Framework. In Transactions of the Martin Centre, vol. III. Edited by JP Steadman and J. Owers. Cambridge: Woodhead-Faulkner.

Laurini, R., 2001. Information Systems for Urban Planning: a Hypermedia Co-operative Approach. London: Taylor and Francis.

Laurini, R. and Thompson, D., 1999. Fundamentals of Spatial Information Systems. London: Academic Press.

\section{References from Other Literature:}

Gocmen, Z.A. (2009). GIS Use for Planning in Wisconsin's Public Agencies. Paper presented at the $11^{\text {th }}$ International Conference on Computers in Urban Planning and Urban Management.

Horn R.E. and Weber, R.P., 2007. New Tools for Resolving Wicked Problems: Mess Mapping and Resolution Mapping Processes. MacroVU(r), Inc. and Strategy Kinetics, LLC. 
Schneider, S., Sarukhan, J., Adejuwon, J., Azar, C., Baethgen, W., Hope, C., Moss, R., Leary, N., Richels, R., Van Ypersele, J.P., 2001. Overview of impacts, adaptation, and vulnerability to climate change. In: McCarthy, J.J., Canziani, O.F., Leary, N.A., Dokken, D.J., White, K.S. (Eds.), Climate Change 2001: Impacts, Adaptation, and Vulnerability. Contribution of Working Group II to the Third Assessment Report of the Intergovernmental Panel on Climate Change. Cambridge University Press, Cambridge, UK.

Svedin, U. and Aniansson, B., 1987. Surprising Futures. Swedish Council for Planning and Coordination of Research, Sweden.

Vlado, V., 1993. GIS-based Information System for Evaluation of Compatibility Between Settlement Activities and their Environmental Settings. PAP-4/GIS/W.1/3. Split: PAP/RAC. pp. 11. ENG.

Wilbanks, T.J., Romero Lankao, P., Bao, M., Berkhout, F., Cairncross, S., Ceron, J.-P.,Kapshe, M., Muir-Wood, R., Zapata-Marti, R., 2007. Industry, settlement and society. In: Parry, M.L., Canziani, O.F., Palutikof, J.P., Van der Linden, P.J., Hanson, C.E. (Eds.), Climate Change 2007: Impacts, Adaptation and Vulnerability. Contribution of Working Group II to the Fourth Assessment Report of the Intergovernmental Panel on Climate Change. Cambridge University Press, Cambridge, UK. 
Appendix 1: Process flow for analysing environmental impacts for e-DIA

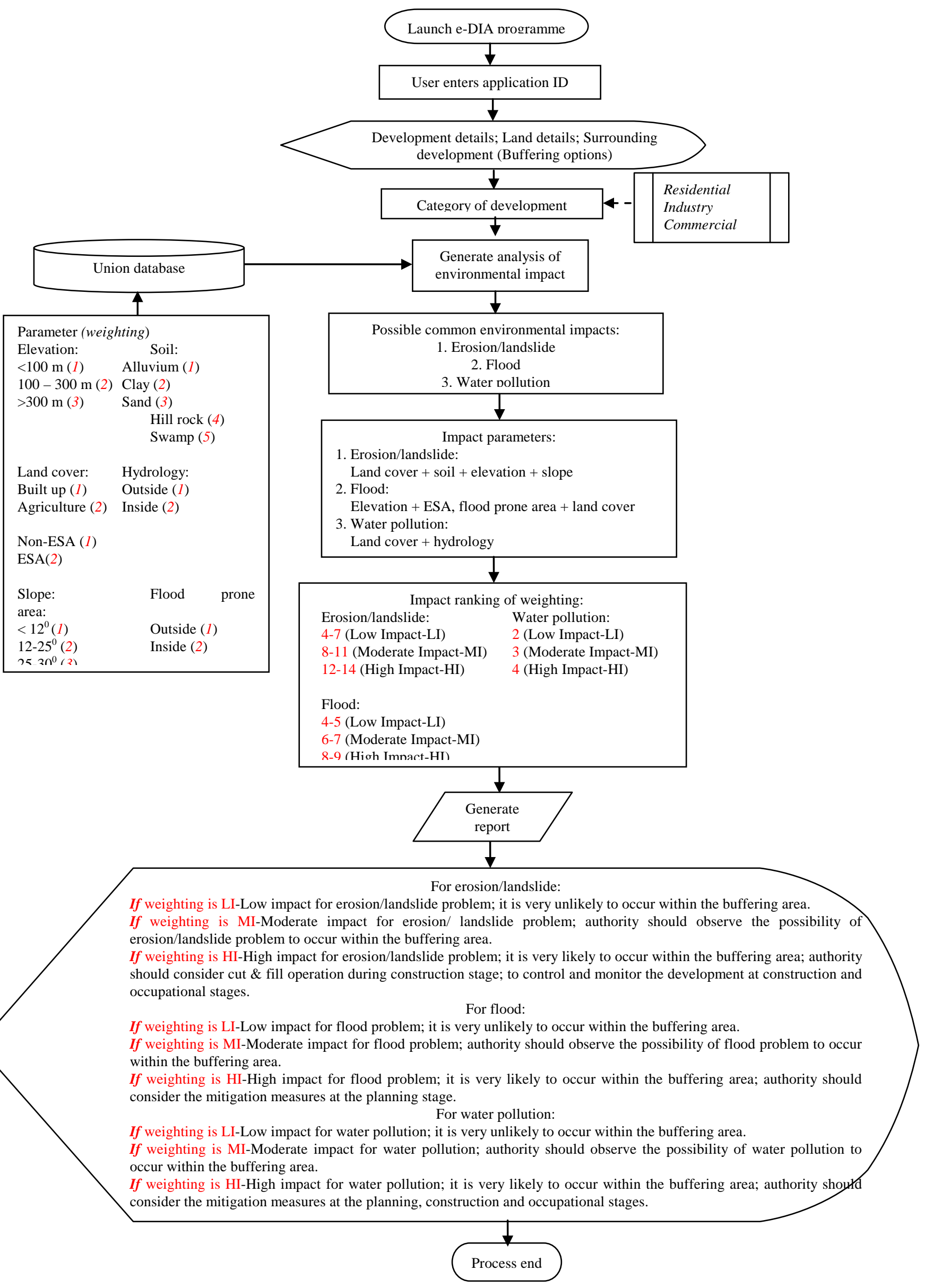


International Archives of the Photogrammetry, Remote Sensing and Spatial Information Sciences, Volume XXXVIII-4/C21 